\title{
The High CoST OF IPOS DePRESSES VENTURE CAPITAL IN THE UNITED STATES
}

\author{
Dale A. Oesterle*
}

The fundamental reason for the small numbers of IPOS is the reluctance of public investors to buy IPO stock. The technology bubble burst in 2000 and investors still remember their losses in the IPO industries. But the IPO market would be more active if IPOs were not so expensive. They cost too much to do and, once done, a company has much higher ongoing costs. The higher ongoing costs are a significant bone of contention, particularly with the implementation of Section 404 of the Sarbanes-Oxley Act of 2002.

Lowering the cost of IPOs would not only enable small companies to net more money per offering, it would also enable small companies to float smaller offerings. And lowering the cost of IPOs is something that the Securities and Exchange Commission could do by allowing small companies to make their IPOs over the Internet. The SEC's foot-dragging on the use of the Internet for IPOs is depressing venture capital in the United States. The most active venture capital IPO market for small companies is now the AIM market in London.

This comment briefly describes the current regulation of $I P O s$, describes an alternative system of public offering that uses the Internet, and concludes with a discussion of whether there are regulatory problems with a system of Internet IPO.

Entrepreneurs in the United States depend on venture capital for funding the formative years of their operations. ${ }^{1}$ The willingness of venture capitalists, ${ }^{2}$ angels, ${ }^{3}$ and venture capital funds ${ }^{4}$ to place funds with portfolio

\footnotetext{
* Dale A. Oesterle is the J. Gilbert Reese Chair at The Ohio State University Moritz College of Law.

${ }^{1}$ William K. Sjostrom, Jr., Relaxing the Ban: It's Time to Allow General Solicitation and Advertising in Exempt Offerings, 32 FLA. ST. U. L. REV. 1, 6 (2004).

${ }^{2}$ Venture capital is money provided by professionals who invest alongside management in young, rapidly growing companies that have the potential to develop into significant
} 
companies depends on predictions of high rates of return for these high risk investments. ${ }^{5}$ The most robust of these predictions depend on the anticipated sale of the company within the next seven to ten years to the public, in an Initial Public Offering ("IPO"). ${ }^{6}$ Since the number of IPOs has been down for the past several years, venture capital funding has been correspondingly flat.

The fundamental reason for the small numbers of IPOs is, of course, the reluctance of public investors to buy IPO stock. The technology bubble burst in 2000 and investors still remember their losses in the IPO industries. $^{7}$ But the IPO market would be more active if IPOs were not so expensive. They cost too much to do and, once done, a company has much higher ongoing costs. The higher ongoing costs are a significant bone of contention, particularly with the implementation of Section 404 of the Sarbanes-Oxley Act of 2002. ${ }^{8}$ This paper, however, will focus on the costs of the IPO itself.

In the United States, a small company has to pay too much in fees and discounts when it sells its stock to the public. A small company selling fifty million dollars of its equity, as measured by the market price at the end of the first day, of an IPO with a market value of over fifty-three and a half

economic contributors. Nat'l Venture Capital Ass'n, The Venture Capital Industry: An Overview, http://www.nvca.org/def.html (last visited Aug. 4, 2006).

${ }^{3}$ Angel investors are typically high net-worth individuals with substantial business and entrepreneurial experience. Sjostrom, supra note 1, at 5. See also UnITED STATES GeNeral ACCOUNTING OFFICE, REPORT TO THE CHAIRMAn, COMMITTEE ON SMALl Business, U.S. SENATE, SMALL BUSINESS: EFFORTS TO FACILITATE EQUITY CAPITAL FORMATION 10 (2000), http://www.gao.gov/archive/2000/gg00190.pdf. [hereinafter GAO REPORT] (describing the usual role of angel investors in small business equity capital creation).

${ }^{4}$ Professionally managed venture capital firms generally are private partnerships or closely-held corporations funded by private and public pension funds, endowment funds, foundations, corporations, wealthy individuals, foreign investors, and the venture capitalists themselves. Nat'l Venture Capital Ass'n, supra note 2.

${ }^{5}$ GAO REPORT, supra note 3 , at 10 (noting that both venture capital funds and angel investors tend to focus on high-growth, high-return investment opportunities).

${ }^{6} \mathrm{Id}$. A future IPO also provides a valuable exit opportunity for investors to liquidate their investments through sale to the public. See also Douglas J. Cumming \& Jeffrey G. MacIntosh, Venture-Capital Exits in Canada and the United States, 53 U. TORONTO L. J. 101, 104-05 (2003) (study concluding that IPO exits are central to the venture-capital process, and the most selected form of exit for highly-valued firms).

${ }^{7}$ See Jay R. Ritter \& Ivo Welch, A Review of IPO Activity, Pricing, and Allocations, 57

J. FIN. 1795, 1796 (2002) (identifying the decline in IPO volume from $\$ 65$ billion in 2000 to $\$ 34$ billion in 2001).

${ }^{8}$ See, e.g., Rebecca Buckman, Tougher Venture: IPO Obstacles Hinder Start-Ups, Wall ST. J., Jan. 25, 2006, at C1; Andrew Parker \& Sundeep Tucker, Sarbanes-Oxley Reforms 'Go Too Far' Says Author, FIN. TIMES (London), July 8, 2005, at 6; Todd M. Malan, Letter to the Editor, Capital Markets Marching to SOX-less Europe, WALL ST. J., June 5, 2006, at A11. 
million ${ }^{9}$ can net only forty-five million dollars in cash or less, a seventeen percent or more charge. ${ }^{10}$ More perversely, those who charge to do the IPOs, underwriters, are uninterested in the smaller offerings; underwriters do not make enough money on the small offerings to justify their expenditure of time on them. A small company that wants to raise twentyfive million dollars cannot find an underwriter; a fifty million dollar IPO is a practical minimum. ${ }^{11}$

Lowering the cost of IPOs would not only enable small companies to net more money per offering, ${ }^{12}$ it would also enable small companies to float smaller offerings. ${ }^{13}$ And lowering the cost of IPOs is something that the Securities and Exchange Commission ("SEC") could do by allowing small companies to make their IPOs over the Internet. ${ }^{14}$ The SEC's footdragging on the use of the Internet for IPOs is depressing venture capital in the United States. ${ }^{15}$ The most active venture capital IPO market for small companies is now the AIM market in London. ${ }^{16}$

This comment briefly details the current regulation of IPOs, describes an alternative system of public offering that uses the Internet, and concludes with a discussion of whether there are regulatory problems with a system of Internet IPOs.

\section{THE UNITED STATES IPO}

\footnotetext{
${ }^{9}$ Assuming an underpricing of approximately seven percent, see Table 1, infra.

${ }^{10} \$ 53.5$ million (value) - $\$ 3.5$ million (underpricing, Table 1 , infra) - $\$ 5$ million (estimated fees/expenses).

${ }^{11}$ GAO REPORT, supra note 3, at 22 (stating that businesses doing IPOs of less than $\$ 50$ million have difficulty in attracting larger investment banking firms to underwrite the offerings, due to high fixed costs and economies of scale, and are distributed by lowertier investment banks that are less attractive to potential investors).

${ }^{12}$ Anita Anand, The Efficiency of Direct Public Offerings, 7 J. SMALl \& EMERGING Bus. L. 433, 438 (2003).

${ }^{13}$ See id. at 453 (noting that equity "direct public offerings" have typically been completed by smaller issuers trying to raise a small amount of capital).

${ }^{14}$ See id. at 439.

${ }^{15}$ See Final Report of the Advisory Committee on Smaller Public Companies ("ACSPC") to the Securities and Exchange Commission (2006), http://www.sec.gov/ info/smallbus/acspc/acspc-finalreport.pdf (last visited Aug. 4, 2006), at 75:

$[\mathrm{H}]$ owever, the current ban on general solicitation and advertising effectively prohibits issuers from taking advantage of the tremendous efficiencies and reach of the Internet to communicate with potential investors who do not need all the protections of the Securities Act's registration requirements. In our view, this is a significant impediment to the efficient formation of capital for smaller companies, one that could easily be corrected by modernizing the existing prohibitions on advertising and general solicitation.

${ }^{16}$ The AIM market had 513 IPOs through April 2006, compared with the NASDAQ's 135. See generally Colleen O'Connor, London's AIM Calls to US VC Community; Stateside seminars perfectly times to catch wave of Sarbox discontent, INVESTMENT DEALER's Digest, Jan. 30, 2006.
} 
A small company undertaking an IPO in the United States will pay three percent or more of the size of the offering to lawyers, accountants and advisers. It will also pay the typical rate of seven percent, or more, for an underwriter. ${ }^{17}$ Finally, the small company will watch as its stock trades at seven percent or more above the offering price on the first day (see Table 1, below).

Table 1: IPO Underpricing Across Different Markets ${ }^{18}$

\begin{tabular}{|l|l|}
\hline Market & Median First-Day Return (\%) \\
\hline UK - Main Market & 4.4 \\
\hline UK - AIM & 11.2 \\
\hline US - NYSE & 5.1 \\
\hline US - NASDAQ & 6.6 \\
\hline
\end{tabular}

The total charge after expenses and underpricing can average over seventeen percent of the value of the stock sold, as measured at the end of the first day of trading. 19

${ }^{17}$ See Sean J. Griffith, Spinning and Underpricing: A Legal and Economic Analysis of the Preferential Allocation of Shares in Initial Public Offerings, 69 BROOK L. REV. 583, $592 \mathrm{n} .25$ (2004) (discussing the debate surrounding the use of the seven percent underwriting fee standard, and adopts seven percent as the standard underwriter commission for the purposes of the article).

${ }^{18}$ Oxera Consulting LtD., The Cost of Capital: An International Comparison 21 (2006). The data cited in this study is derived from Oxera calculations based on the Bloomberg financial database.

The median first-day return on a NASDAQ IPO represents the middle-range in the amount by which the initial offering price of an IPO is less than the actual market value, signified by its return after the first day of trading. This "underpricing" may be a means by which underwriters generate investor interest by offering the stock at a price under its actual market value, which will help these initial investors realize a short-term gain from the resulting price increase in the secondary market. Christine Hurt, Moral Hazard and the Initial Public Offering, 26 CARDOZO L. REV. 711, 724-25 (2005).

The average underpricing rate over long periods usually resides between ten and twenty percent. See Tim Loughlin \& Jay Ritter, Why Has IPO Underpricing Changed Over Time?, Financial Management, Vol. 33, No. 3, 5 (Autumn 2004), available at http://bear.cba.ufl.edu/ritter/publ_papers/Why\%20has\%20IPO $\%$

20Underpricing $\% 20$ Changed $\% 200$ ver\%20Time.pdf (average first day return was seven percent in the 1980s, rose to fifteen percent between 1990 and 1998, sixty-five percent during the technology bubble of 1999-2000, then fell to twelve percent in 2001 through 2003).

${ }^{19}$ This difference between a firm's gain from the sale and the actual market value of what was sold is significant when considering the future return promised to shareholders. Consider the difference between a promised return of ten percent on an IPO with a market capitalization of $\$ 50$ million. After fees and expenses, the company's net gain would only be $\$ 45$ million. With this reduced gain, the $\$ 5$ million return promised to shareholders would require increasing the return from ten percent to eleven percent. 
The high fees, the underwriting discount and the under-pricing of the shares are all due to the underwriting process mandated by existing SEC rules. The rules are well-known and deserve only a brief mention here.

SEC rules break down the underwriting process into three periods: the pre-filing period, the waiting period, and the post-effective period. The periods are defined by four dates. When a company is "in registration" (usually thirty days before the filing of a registration statement) and until it files a registration statement with the SEC, the company is in the pre-filing period and cannot make offers or sales of its securities. From the filing of the registration statement until the SEC declares the statement "to be effective," the company is in the waiting period and can make limited types of offers to sell but cannot close any sales. From the effective date until the end of the "distribution," the company is in the post-effective or distribution period and can sell the stock if it delivers a formal selling document, the final prospectus, to purchasers.

Most IPOs are conducted as firm commitment offerings. ${ }^{20}$ A syndicate of investment banks underwrites the offering. ${ }^{21}$ The syndicate purchases the entire allotment of new shares and resells them to the public during the distribution period. ${ }^{22}$ One of the underwriters, the lead or bookrunning manager, will take the primary role in organizing the offering. ${ }^{23}$ The night before the distribution period begins, the issuing company and the lead underwriter will agree on the public offering price, and the formal underwriting agreement that prices the shares will be executed the following morning. ${ }^{24}$ The underwriter solicits views on price during the waiting period. ${ }^{25}$ Until 2005 , general advertising solicitations were tightly controlled. Since 2005, underwriters, acting on behalf of issuers, can use a "free writing prospectus" exception to broadcast offers to the public in any media. $^{26}$

\footnotetext{
${ }^{20}$ Taylor J. Hart, Distributing Debt Securities in Cyberspace: How the Internet May Permanently Alter the Role of Underwriters, 35 SUFFOLK U. L. REV. 395, 398 (2001).

${ }^{21}$ GAO REPORT, supra note 3, at 75.

${ }^{22} \mathrm{Id}$. at $75-76$.

${ }^{23}$ NASDAQ, Going Public: A Guide For North American Companies to Listings ON THE U.S. SECURITIES MARKETS 21 (Nicole Lew ed., White Page LTD 2005), available at http://www.nasdaq.com/about/gp_guide_2005.pdf. The lead book-running investment bank may also manage the syndicate to ensure healthy competition and investor demand. $I d$.

${ }^{24}$ William K. Sjostrom, Jr., Going Public Through an Internet Direct Public Offering: A Sensible Alternative for Small Companies?, 53 FLA. L. REV. 529, 539 (2001).

${ }^{25} \mathrm{Id}$. The waiting period is the period between the filing of the registration statement and its effective date. $I d$. at 554 .

${ }^{26}$ Written offers, including electronic communications, outside those previously permitted by the Securities Act are allowed, provided certain conditions are met. Securities Offering Reform: Final Rule, 70 Fed. Reg. 44722, 44744 (2005) (adding the definition of a "free writing prospectus" to the Securities Act Rule 405).
} 
A pricing variant that is much discussed and was used by Google is the Dutch auction offering. ${ }^{27}$ There is no fixed price. Investors place bids for a desired number of shares at or below a specified price. ${ }^{28}$ The issuer selects the highest price that will sell out the offering and all investors who had bid that price or higher pay the selected price. ${ }^{29}$ There have been high hopes by companies that Dutch auction offerings would limit the underpricing of the shares and companies would leave less "money on the table." 30 However, the results of the auctions, not popular with investment bankers, ${ }^{31}$ have been mixed. ${ }^{32}$

Companies that cannot find investment banks willing to do a firm commitment underwriting are left with a less desirable alternative, the best efforts offer. ${ }^{33}$ The investment bank does not purchase and resell the securities, ${ }^{34}$ a dealer role, but instead acts as a selling agent, a broker, and receives a commission for each security sold. ${ }^{35}$ In a conditional best efforts offering, an all or nothing offering, the issuer promises to rescind all the

${ }^{27}$ See, e.g., Eugene Choo, Note, Going Dutch: The Google IPO, 20 BERKELEY TECH. L. J. 405 (2005); Brianne M. Hess, Comment, Google, Inc.: The Dutch Auction Approach as an Alternative to Firm Commitment Underwriting, 7 DuQ. Bus. L.J. 89 (2005); Christine Hurt, What Google Can't Tell Us About Internet Auctions (And What It Can), 37 U. TOL. L. REv. 403, 414 (2006).

${ }^{28}$ Hess, supra note 27 , at 98.

${ }^{29}$ Id.

${ }^{30}$ See James Surowiecki, How To Do An IPO, SLATE, Dec. 9, 1999, $\mathrm{http}: / /$ www.slate.com/id/1004150 (stating that the Dutch auction is "a superior way of pricing an IPO because no one gets shares on the basis of who they know, and because it ensures that the company going public isn't going to leave too much money on the table by going public at a lower price than the one the market was willing to pay").

${ }^{31}$ See generally Hurt, supra note 18 , at 765 (although the author is referring to online auctions, Dutch auctions are similarly regarded by investment bankers). Further, as issuers generally choose an underwriter early in the IPO process, the underwriter will likely not counsel the issuer to investigate the possible benefits of the online IPO. Id. at 770 .

${ }^{32}$ The Google IPO cannot be considered representative of the value of the Dutch auction process due to its uniqueness as an issuing company. Hurt, supra note 27 , at 435. Further, the criteria one values in a "successful" auction IPO is itself conflicting. While many consider an increase in share price from excessive demand to denote a successful offering, proponents of the auction process may consider the degree to which the initial offer price mirrors the market price as signifying a successful auction. Id. at 428. Hambrecht, a major U.S. supporter of the auction process, "considers an auction IPO with a first-day pop of $10 \%$ or more a failure." Id.

${ }_{33}$ Best efforts offerings are most common with more speculative securities or with new issuing companies. GAO REPORT, supra note 3, at 75-76.

${ }^{34}$ The underwriter may agree either to only purchase as many shares as they can successfully resell, or act only as brokers and aid in finding willing investors. Id at 75 . ${ }^{35}$ Thus, the underwriter assumes no financial risk for the sale of new shares as the issuing company retains ownership rights over these shares. Id. at 24 n.20. 
sales if the offering is not sold out. ${ }^{36}$ Investors discount the price of the shares to reflect the higher valuation risk, reflecting the investment bank's lack of confidence in the securities.

It is within the SEC rules for companies to do a direct public IPO (or "DPO"), an offering by the company directly to the public without an underwriter. ${ }^{37}$ Few are tried and many of those that are tried fail. ${ }^{38}$ Investment banks argue that investors shy away from offerings that do not have the certification of an underwriter who has backed the offering with its reputation and exposure to liability for errant company claims. Moreover, those companies whose securities do not meet the listing requirements of a national securities exchange or the NASDAQ must register with all those states in which stock will be sold. ${ }^{39}$ This can be a substantial burden for some DPOs. ${ }^{40}$ Finally, the hostility of investment banks towards DPOs also affects the willingness of the major players in the investment community to invest robustly in DPOs; they cannot risk jeopardizing their ongoing business relationships with the banks. Thus, for most issuers, a DPO is currently only a financing option of last resort. ${ }^{41}$

Firms have emerged that offer DPO expertise. ${ }^{42}$ Some will prepare registration documents, hyperlink marketing programs, website consultations and creation, and oversight of the registration process. ${ }^{43} \mathrm{At}$ issue is whether such experts in registered DPOs are underwriters or just securities marketing specialists. ${ }^{44}$ Those experts that do registered DPOs may be underwriters under the Securities Act of 1933 and be subject to the Act's Section 11 liability. ${ }^{45}$ If so, those experts must perform due diligence similar to that undertaken by investment bank underwriters in firm

\footnotetext{
${ }^{36}$ StePhen J. Chol \& A.C. Pritchard, SECurities Regulation: CASES AND ANALySis 414 (2005).

${ }^{37}$ See Sjostrom, supra note 24, at 540-544. A DPO must either register with the SEC, or qualify for an exemption under either Rule 504 (17 C.F.R. $\$ 230.504$ (2000)) or Regulation A (17 C.F.R. $\S \S 230.251-263$ ). Rule 504 and Regulation A companies are exempted as "small offerings." A Rule 504 offering is capped at \$1 million and a Reg. A offering at $\$ 5$ million.

${ }^{38}$ Sjostrom, supra note 24, at 581 (stating that of the 2,000 DPOs of companies from 1990 to 2001 only 156 still publicly trade).

${ }^{39} I d$. at 544 (stating that registration is required unless the company fits an exemption within that state).

${ }^{40} I d$. at 544545 . The DPO issuer will likely have to register the offering or structure it to meet the exemption requirements in the intended states for selling the offering, each of which has their own individual blue sky laws that often lack uniformity in areas such as registration requirements and exemptions.

${ }^{41}$ Id. at 585 .

${ }^{42}$ Also known as "cyber middlemen." Id. at 591.

${ }^{43}$ Id.

${ }^{44}$ These intermediaries do not typically have strong enough reputations with investors to provide trusted assurances to the investor, nor is it clear whether these intermediaries perform any investigations of their issuer clients. $I d$. at 592.

${ }^{45}$ See id. at 594 n.27.
} 
commitment underwritings to limit their liability exposure, and investors may similarly rely on these investigations. ${ }^{46}$ Since established investment banks have not chosen to offer these DPO services, however, the reputation and the solvency of the DPO experts is not equal to traditional underwriters. ${ }^{47}$

\section{THE AIM}

The London Stock Exchange is successfully marketing a low cost public offering process to small companies, entitled the Alternative Investment Market ("AIM"). ${ }^{48}$ The AIM caters to companies in the micro to small cap universe, ${ }^{49}$ offering access and liquidity comparable to NASDAQ at a lower total cost to the issuer. ${ }^{50}$ Small companies can raise capital on the AIM with fees and underwriting charges that are thirty percent of those incurred in the United States markets. ${ }^{51}$ Under-pricing losses are less as well. ${ }^{52}$ Smaller offerings with a consideration of less than 2.5 million Euros may also qualify for an exemption from filing a prospectus, further eliminating associated costs when compared to a listing on the NASDAQ. ${ }^{53}$ Finally, the listing process takes only eight to twelve weeks, compared to the six to eight months required in the United States. ${ }^{54}$

\footnotetext{
${ }^{46}$ See id. at 594 n.29.

${ }^{47}$ Further, these intermediaries may dispute whether their performance responsibilities fit the definition of an "underwriter," and argue against Section 11 liability. Id.

${ }^{48}$ See generally London Stock Exchange, Welcome to AIM, http://www.londonstockexchange.com/engb/products/companyservices/ourmarkets/aim_new (last visited Aug. 6, 2006) (providing background information, market data, and training materials for the AIM). ${ }^{49}$ The average market value for an AIM company was $\$ 71$ million last year, compared with $\$ 1.2$ billion on the NASDAQ. Edgar Ortega \& Nandini Sukumar, London's AIM snaps up small companies, SUNDAY TRIBUNE (Ireland), June 11, 2006, at B8.

${ }^{50}$ The estimated expense to execute an IPO on the AIM is thirty percent less than on the NASDAQ. Charley Lax, PE Week Wire, $\mathrm{http} / /$ www.grandbankscapital.com/news/pressrelease.cfm?news item id=578 (last visited Sept. 9, 2006). Further, the cost of maintaining a listing on the AIM is sixty percent less than maintaining a listing on the NASDAQ, due largely to SOX 404 compliance costs. $I d$.

${ }^{51}$ See id.

${ }^{52}$ Oxera Consulting Ltd., The Cost of CAPITAL An International Comparison 21 (2006).

${ }_{53}$ Pinsent Masons, Financial Services \& Insurance: The Prospectus Directive - Impact on Alternative Investment Market (AIM),

http:/www.pinsentmasons.com/media/225081526.pdfHsearch=\%22FSA\%20Prospectus $\% 20$ Directive\%22_(last visited Sept. 25, 2006).

${ }^{54}$ See LONDON STOCK EXCHANGE, A PROFESSIONAL HANDBOOK: JOINING AIM 59 (2006), http://www.londonstockexchange.com/NR/rdonlyres/2FFDF9AD-2A8A-4EE6B094-0A505E922F9A/0/LSEAIMGuidenographicsFINAL.pdf (last visited Sept. 9, 2006) at 29 (showing a graphical depiction of the listing process before admission in the twelfth week).
} 
The AIM market has limited listing requirements. ${ }^{55}$ There is no minimum share requirement, no trading record requirement, no shareholder approval requirement, and no minimum market capitalization requirement. ${ }^{56}$ In addition to a working capital report, ${ }^{57}$ only two years of audits are required and a report on internal financial controls. A listed company must have a "nominated advisor" and declare its working capital. ${ }^{58}$ The Nominated Advisor ("Nomad") vouches for the company, determining its suitability for AIM, and will do due diligence, but the requirements are less stringent than those for a full listing. ${ }^{59}$ The Nomad's certification provides the substitute for the underwriter's certification in the United States.

Most of the AIM companies go public through a so-called private placement (it does not have the same meaning in the United States), in which a company's shares are offered to a select group of institutional investors that include well known names in the United States: Fidelity, Goldman Sachs and Merrill Lynch. ${ }^{60}$

The AIM market is booming. In 2005, the AIM had three hundred and thirty-five IPOs compared to NASDAQ's thirty-five. ${ }^{61}$ The deal size comparisons are also telling. The average technology IPO deal size on the NASDAQ was $\$ 120$ million, on the AIM it was $\$ 19$ million. $^{62}$ The AIM supported the smaller deals. AIM investors were willing to accept more risk, as the enterprise value was around six times revenue, as compared with the NASDAQ's enterprise value of around five times revenue. ${ }^{63}$ The London market has successfully created a public offering market for small and micro cap companies. To remain competitive, the United States trading markets need to mount a successful competitor to this market.

\section{What COULD BE ...}

\footnotetext{
${ }^{55}$ The main component of the listing requirements is the admission document. $I d$. at 31 , Table 2 (contains the complete list of requirements).

${ }^{56}$ LONDON STOCK ExChange, AIM: Admission Criteria and Process, http://www.londonstockexchange.com/en$\mathrm{gb} /$ products/companyservices/ourmarkets/aim_new/About+AIM/admissioncritera.htm (last visited Sept. 9, 2006).

${ }^{57}$ See generally LONDON STOCK EXCHANGE, supra note 54, at 59 (details, purpose, and requirements of the working capital report).

${ }^{58} I d$.

${ }^{59}$ Id. at $18-27$.

${ }^{60}$ Grace Wong, The War for Start-Ups Going Public, CNN Money.com, http://cnnmoney.com/2006/06/14/smbusiness/vc.aim/index.htm (last visited Sept. 4, 2006).

${ }^{61}$ These comparisons were drawn from data available at the websites of both the AIM and the NASDAQ. Monthly data for the AIM is available at http://www.londonstockexchange.com/en$\mathrm{gb} /$ pricesnews/statistics/factsheets/aimmarketstats.htm. NASDAQ data may be found at http://www.nasdaq.com.

${ }^{62}$ See id.

${ }^{63}$ See id.
} 
The AIM market suggests the obvious; the United States needs a more flexible system of public offerings. Small companies in the United States should be able to more easily go public with DPOs offered through the Internet. The goal would be an eBay style system for small companies. Run a Dutch auction for your shares on the Internet. Regulatory changes necessary to stimulate such a market would include:

1. Expanding the scope of federal pre-emption of state blue sky laws. Defining "covered securities" under Section 18 of the Securities Act of $1933^{64}$ should include those companies traded on alternative trading markets such as the NASDAQ Bulletin Board.

2. Tighten the definition of underwriter under the 1933 Act to exclude securities marketing experts in registered DPOs unless those experts self-declare that they are underwriters. Those that self declare as underwriters are liable for a failure of due diligence (intentional complicity, recklessness, or negligence) if there are misleading statements or omissions in the offering materials.

3. Reduce the registration requirements for smaller companies that choose to trade on the alternative trading markets.

a. Two years of audited financials, an identification of the principals, and a declaration of a business purpose should be enough to register. Companies could choose to offer more information or bind themselves to stronger disclosure obligations or internal control procedures.

b. No form limits on Internet offerings or auctions. Internet offerings could start during the waiting period, with sales and/or auctions starting in the post-effective period. Sanctions for securities fraud (Rule 10b-5) would continue to apply.

The changes would give small companies an option of raising capital in our public markets at lower costs and in lower amounts.

\section{THE OBJECTIONS}

The primary two objections to an easy, inexpensive method of auctioning stock of small companies on the Internet are, first, increased and unacceptable levels of promoter fraud, ${ }^{65}$ and, second, increased and

\footnotetext{
${ }^{64} 15$ U.S.C. $\$ 77 \mathrm{r}$ (b)(1)(a) (2001). A covered security is one that listed or approved for listing on the NYSE (or an approved regional exchange) or a national market system security on the NASDAQ. Professor Sjostrom has a similar suggestion. Sjostrom, supra note 24 , at $587-88$.

${ }^{65}$ Both small businesses and the Internet have each been associated with a high amount of fraudulent activity. Sjostrom, supra note 24, at 583. See also Arthur Levitt Jr., A Misguided Exemption, WALL ST. J., Jan. 27, 2006, at A8 ("Consider that these [small] companies are the ones most likely to have internal control problems, and least likely to have analysts, institutional investors and the media watching them."); Steven Davidoff,
} 
unacceptable investor speculation. ${ }^{66}$ The first argument is the more serious of the two.

Small companies have been responsible for a large proportion of the instances of investor fraud. ${ }^{67}$ By allowing small companies to make Internet offerings will we be giving the green light to the scam artists? No doubt more will try. Better investor education and stronger enforcement efforts should make the increase in fraud bearable, however. Moreover, the increase in fraud will be offset by the increase in legitimate business activity stimulated by the reduced costs of raising capital for many of our most innovative and productive companies.

I also suspect that our fear of scams is overblown, supported by those who stand to lose the most from the new IPO methods - investment banks. Investment banks, just as brokers did when fixed commissions were nixed, may find that new profitable opportunities have increased, not decreased, and that their old business for the larger companies survives and flourishes.

Investors will use the Internet offerings and the subsequent trading in the IPO stock as speculative opportunities. There can be no doubt. Day traders will plumb the new stocks for speculative gains. It is a better alternative to casino gambling. Gambling funds directed into stocks have a socially useful side (in addition to entertainment value); casino gambling does not. I would much rather have those in our casinos and sports betting parlors direct their money into the stock market than keep the funds where they are.

\section{CONCLUSION}

The Internet has created an opportunity to allow our smaller companies to raise public capital in smaller amounts and at much lower

Comments on Business Law Professor Blog,

$\mathrm{http}: / /$ lawprofessors.typepad.com/business_law/2006/08/londons_aim.html\#comments (last visited Aug. 22, 2006) ("These [small and microcap firms] are much riskier companies reflected in the higher risk premium....This, combined with minimal disclosure requirements and limited available research makes them ripe for manipulation and investor fraud. Not to mention higher failure naturally."); SEC, Pump\&Dump.con: Tips for Avoiding Stock Scams on the Internet, http://www.sec.gov/investor/pubs/pump.htm (last visited Aug. 21, 2006) (detailing the "pump-and-dump" scheme used by Internet defrauders).

${ }^{66}$ See Sjostrom, supra note 24 , at 582 ("Potential investors ... generally have no costeffect [sic] way to evaluate the accuracy and completeness of the disclosure and assess the fairness of the offering.").

${ }^{67}$ See ACSPC Final Report, supra note 15, at 139 (" [T] have more misstatements and restatements of financial information, nearly twice the rate of large firms....A larmingly, these small firms also make up the bulk of accounting fraud cases under review by regulators and the courts (one study puts it at 75 percent of the cases from 1998-2003)."). 
cost. We should take advantage of the new technology and not let our fears of an unknown scam potential stymie our efforts. 